The Eastern Librarian, Volume 23(1), 2012, ISSN: 1021-3643 (Print). Pages: 1-23.

Available Online: http://www.banglajol.info/index.php/EL

\title{
CHANGING PARADIGMS IN LIBRARY EDUCATION: FROM LIBRARY SCIENCE TO INFORMATION SCIENCE TO KNOWLEDGE SCIENCE
}

\author{
Md. Roknuzzaman, $\mathrm{PhD}$ \\ Department of Information Science and Library Management, \\ University of Dhaka, Dhaka-1000, Bangladesh. \\ E-mail: mrkzaman@yahoo.com
}

\begin{abstract}
The main objective of this paper is to explore the changes in library education in the context of the emergence of both 'information science' and 'knowledge management'. This paper is based on the review of scientific literature published in books, journals, websites, and other secondary sources and on the author's own viewpoints. The review discusses library science's encounter with information science, and shows the changes in the paradigm of library science from library-orientation to information focus. In the context of renaming the discipline of library science as library and information science (LIS), this paper explores the curricular trends and the changes in the professional practice of librarianship. The discipline of LIS is now encountering with the emergence of knowledge management (KM), and is moving towards knowledge paradigm. The review also identifies some factors that influenced the change in library education and practice. The paper concludes with the prediction of a new discipline of "knowledge science" suggesting the renaming of library and information science as "library and knowledge science".
\end{abstract}

DOI: http://dx.doi.org/10.3329/el.v23i1.12115

\section{KEYWORDS}

Library Education, Library Science, Information Science, Library and Information Science, Knowledge Science.

\section{INTRODUCTION}

The education for librarianship has become an enormously vibrant field incorporating emerging elements such as information science, information management, digital libraries, Internet, library 2.0, etc. Library education was

1 The Eastern Librarian-peer-reviewed journal in LIS since 1965 
formally started at Columbia University, USA in 1887 with the establishment of the School of Library Economy by Melvil Dewey (Wilson \& Hermanson, 1998). But the most influential drive toward the emergence of library science was the establishment of the Graduate Library School (GLS) at the University of Chicago in 1926 (Richardson, 1982). With the emergence of information science after World War II, the field of library science experienced dramatic changes. The profound impact of information and technology on the library environment has altered the face of traditional librarianship, and library education has acquired a new platform by incorporating the information paradigm into its name. The rapid evolution of the discipline exerts a great effect on its education and practice, affecting both content and pedagogy.

In "Roadmap to change: Emerging roles of information professionals", Omekwa and Eteng (2006) asserted that The School of Information Studies at Syracuse University (2002) has rightfully observed:

"at the start of the $21^{\text {st }}$ century, libraries find ... cultural and social transformation. Technological advances have redefined the information environment ...The library profession is evolving, redefining itself to meet the challenges of the changing environment. In an era in which increasing sectors of the economy are devolved to information management, the librarian's task will be to translate the profession's traditional values and expertise to meet the demand of the new environment" (p.268).

The dominant paradigm of information has thus redefined and reengineered the library profession, and has influenced the renaming of library schools. The surveys of the literature and of LIS schools' homepages suggest the diversity of school names, with different combinations of 'library' and/or 'information'. The importance of the name changes reflects a shift from the "library focus" to the "information focus" of the discipline.

The idea of knowledge economy has accelerated the growth of KM - a new paradigm for information processing and innovation. There is a clear indication in the literature that a number of authorities having backgrounds in library and/or information science have contributed to the emergence and development of KM, along with other promoters of KM such as business, management, ICT, and so on. Wen (2005) describes the emergence of KM first in the business sector, then in higher education, and now in library management. Although KM is of recent origin, Sarrafzadeh (2005) finds its older roots in the LIS literature, when Hawkins (2000) claims that for many in the academic world, it is an old concept, a function historically performed by librarians. The movement of KM

2 The Eastern Librarian-peer-reviewed journal in LIS since 1965 
into LIS indicates KM's relevance to LIS, and the fact is that KM has now been incorporated into formal LIS education and practice. Thus library education has encountered with two major events, namely "information science" and "knowledge management", and in such context, the paper examines the pattern of change in library education and explores the causes behind these changes.

\section{OBJECTIVES AND METHODOLOGY}

The main objective of this paper is to examine the encounter of library science with both information science and knowledge management. More specifically, the objectives are as follows:

- to describe the paradigm shift in library education in the context of incorporating information science into library science

- to identify the trends in education and professional practice of librarianship

- to explore the responses of LIS towards the emergence of knowledge management

- to identify the factors which have influenced to change in library education, and

- to suggest a new name for library and information science.

The paper is based on the review of literature and on author's own viewpoints. A comprehensive search of scientific literature with the phrases "library education", "library science", "information science", "information education", "library and information science", "knowledge management", "knowledge management and LIS", "paradigm change in LIS", etc. published in books, journals, online sources, etc. is conducted. A qualitative content analysis of relevant literature is made to address each of the above objectives.

\section{LIBRARY SCIENCE'S ENCOUNTER WITH INFORMATION SCIENCE}

Library science concentrates on the theory and fundamental principles of librarianship, while librarianship is concerned with library practice (Landridge, 1978). As library science is often defined as a theory of library practices (Nitecki, 1993), its intellectual foundations contain the selection, organization, planning, and management of library resources, and guidance in their use (Carnovsky, 1964). The concept of information science emerged and developed after the Second World War. During the 1960s and the early 1970s, academia 
embraced the new discipline of information science, and practitioners in a number of fields claimed information science as their own because of its interdisciplinary nature (Garfield, 1980).

\section{The Library Science vs. Information Science Debate}

Disputes and differences of opinions exist as to the relationship of library science with information science, and therefore, the responses of library science to information science in terms of integration are also various. The lack of consensus, together with the changing state of the profession, has led to an identity crisis of students regarding the nature of information science and its relation to the discipline of librarianship (Alimohammadi \& Sajjadi, 2007). According to Schrader (1995), library science and information science are two different domains, information science is a subset of library science, library science is a subset of information science, both are a unified domain with various combinations of library science and information science, and finally, a superordinate domain encompassing both library science and information science, and frequently many other domains as well (pp. 40-44). The diverse opinions, however, can broadly be categorized into two groups:

\section{Two Different Disciplines}

Authors like Taylor (1966), Borko (1968), Tague (1979), Gleaves (1982), and Saracevic $(1982 ; 1992)$ have argued that information science is an independent discipline. Saracevic (1982) has argued for a separation and divorce of information science from library science. He further considers that librarianship and information science are two different fields in a strong interdisciplinary relation, rather than one and the same field, or one being a special case of the other (Saracevic, 1992).

\section{A Unified Discipline}

Swanson (1965), Hayes (1969; 1994), Apostle and Raymond (1986) among others have argued that information science and library science have become an integrated field of study. Hayes (1994) mentions that together librarianship and information science share common concerns with each of them, but they approach them from different perspectives and with different priorities. Stieg (1992) remarks that "one can regard the two as identical; information science is simply librarianship under another name... a branch of librarianship, a junior partner in an ancient enterprise. Others consider information science the 
theoretical foundation of all the information professions and librarianship one of its application. And finally, there is library-and-information science, the new federated discipline" (p.13).

\section{Incorporation of Information Science into Library Science}

Inspite of having an ambivalent attitude of library science community towards their responses to information science, the decades of the 1960s and the 1970s witnessed the study of information science within the programmes of library schools. Stieg, (1992) mentions that during this period, there was much criticism of the failure of library schools to integrate information science into their curricula, but now this integration has taken place at all levels. A number of studies have shown that information science and technology has a great deal of relevance to library science (Artandi, 1969; Fosdick, 1978, 1984; Tague, 1979; Davis \& Shaw, 1981).

Fosdick found that all information science courses offered in graduate schools of library science fell into five categories, almost similar to Belzer et al.'s (1975) cluster analysis of information science courses. A large majority of the schools (about 80\%) offered courses in library automation, and information storage and retrieval, which appeared to constitute the "core" of information science education in library schools. Systems analysis, interactive computer systems, and programming courses were also taught in some library schools. Tague (1979) found that all of the 7 graduate library schools in Canada incorporated information science components into their curricula without changing their fundamental orientation towards library work. Therefore, she mentioned that 'traditionalists' feel that information science is an integral part of librarianship, and 'nontraditionalists' feel that it is a separate discipline.

\section{Renaming Library Schools: From Library Paradigm to Information Paradigm}

Since 1972, there has been a shift in emphasis from 'library' to 'information science' (Colson, 1980). Durrance (2004) reports that, by the end of 1980s, library school programmes achieved a near total shift from "library"-only focused names to "library and information" or "information and library" designations. Galvin (1995) remarks that the issue of "the L word" is one further status issue peculiar to the information field. Logan and Hsieh-Yee state (2001) that, by 1996, only one of the accredited schools in the U.S. remained a school of library science: most were called "library and information studies" or 
"library and information science", and five omitted the word "library" altogether. By 2000, ten schools out of 56 accredited LIS schools had no mention of "library".

Durrance (2004) further observes that Syracuse University became the first "information school" by not only including information in the name of the program, but by also becoming the first school to drop the designation "library" entirely from its name. The trend continued at an accelerated pace, and by early 2004, nearly one-third of accredited LIS programmes (16 of 52) have chosen to remove "library" from their official names. Thus, a group of "I-schools" has emerged from schools formerly known as schools of library and information science. In a recent study, Alimohammadi and Sajjadi (2007) report that more than $98.5 \%$ (69 out of 70) of library schools in Canada, the USA, and the UK have changed their names, and that less than 45\% (31 out of 70) have changed completely their titles from the traditional forms, e.g., librarianship, library science, and library studies, to the newer ones. The diversity in renaming these library schools is shown in Table 1 and Table 2.

Table 1: Changing Names of LIS Schools in Canada and the USA

\begin{tabular}{|l|c|}
\hline \multicolumn{1}{|c|}{ Names of the schools (Canada and the USA) } & No of schools \\
\hline Library and Information Science/s & 19 \\
\hline Library and Information Studies & 11 \\
\hline Information & 5 \\
\hline Information Studies & 5 \\
\hline Information and Library Science & 3 \\
\hline Information Sciences & 3 \\
\hline Communication, Information and Library Studies & 1 \\
\hline Informatics & 1 \\
\hline Information and Computer Sciences & 1 \\
\hline Information and Media Studies & 1 \\
\hline Information Management & 1 \\
\hline Information Resources and Library Science & 1 \\
\hline Information Science and Learning Technologies & 1 \\
\hline Library and Information Management & 1 \\
\hline Library Science & 1 \\
\hline Library, Archival and Information Studies & 1 \\
\hline \multicolumn{2}{|c|}{ Total } \\
\hline
\end{tabular}

Source: Alimohammadi and Sajjadi (2007) 
Table 2: Changing Names of LIS Schools in the UK

\begin{tabular}{|l|c|}
\hline \multicolumn{1}{|c|}{ Names of the Schools (the UK) } & No of schools \\
\hline Information Studies & 3 \\
\hline Information Management & 2 \\
\hline Information Science & 2 \\
\hline Business Information & 1 \\
\hline Computer and Information Sciences & 1 \\
\hline Computing & 1 \\
\hline Information and Library Management & 1 \\
\hline Information and Communication Studies & 1 \\
\hline Information and Communication & 1 \\
\hline Information and Media & $\mathbf{1 4}$ \\
\hline
\end{tabular}

Source: Alimohammadi and Sajjadi (2007)

\section{Curriculum Renovation and Trends}

The increasing value of information is bringing other professions into the information field, and changing the boundaries and rules of competition. Regarding the changes in LIS curriculum, Logan \& Hsieh-Yee (2001) have emphasized programmes with wider appeal, increased interdisciplinarity, prevalence of technology, specialization, and distributed learning. Some of the trends in curriculum renovation of library schools are as follows:

\section{Increased Inter-and/or Multi-disciplinarity}

The nature and academic settings of information science, described by Saracevic (1979), Svenonius and Witthus (1981), and Borko (1984) indicate its multidisciplinarity, associated with the programs in library science, computer science, business and management, communication, and so on. The amalgamation of library science and information science has made the LIS discipline more inter- and/or more multi-disciplinary. The infusion of multidisciplinary perspectives results as LIS educators conduct research with people from cognate fields, and when they offer joint programmes/courses with other academic departments, and such developments could encourage a fresh examination of LIS, and an appreciation of the field as a kind of meta-discipline, dealing as it does with knowledge (Myburgh, 2003). Logan and Hsieh-Yee (2001) argued that the increased interdisciplinarity observed in LIS 
programmes in terms of departmental mergers, joint faculty appointments and hires from fields outside the traditional LIS fields had a major impact on the types of courses being offered and on the flavor of school curricula.

\section{Broader Information Orientation}

LIS curricula are moving towards the inclusion of more information-oriented programs (Burgess \& Edwards, 1990; KALIPER Advisory Committee, 2000; Pettigrew, 2001; Durrance, 2004). The first trend of LIS education as identified by the KALIPER Report indicates that, in addition to libraries as institutions and library-specific operations, LIS curricula are addressing broad-based information environments and information problems. Durrance (2004) regards this shift as "from a library-focused Ptolemaic model to an information-focused Copernican paradigm.” Durrance's (2004) broad groupings of LIS/IS research also suggest the expansion of the field, with information-related topics including information/knowledge (content), information technology, information systems, and human information behavior.

\section{Greater Infusion of Information Technology}

Information technology is considered by the adherents of the information paradigm as the fundamental factor that underlies all future library developments, and as the driving force that is transforming librarians into "professional information managers" (Raymond, 1997). Van House and Suttton (1996) describe that LIS is in a struggle with other professions and academic disciplines because of two primary reasons: first, changes in computing and telecommunications, and second, the increasing strategic importance of information in our economy and in society more generally. Therefore, the increasing investment in and infusion of information technology in LIS curricula is another important trend reported by the KALIPER project (KALIPER Advisory Committee, 2000). Logan and Hsieh-Yee (2001) observed that basic computer applications courses were dropped in favor of more specialized alternatives- emphasizing networking, hardware and software design, electronic database systems, library systems, and information transfer media. This trend continues and many new courses emerging from the Internet and Web revolutions are being incorporated into library schools. Foo and $\mathrm{Ng}$ (2008) have argued that the advent of the Internet, knowledge management, Web 2.0 and Library 2.0 through the 1990s and 2000s have indeed posed significance challenges for library schools to keep pace with the changes. Not many library schools are now offering Web 2.0 courses; however, some studies

8 The Eastern Librarian-peer-reviewed journal in LIS since 1965 
found that the library school curricula have started to adopt either a specific course on Web 2.0 or on issues related to Web 2.0, such as wikis, blogs, Flickr, collaborative favorites, social networks, weaving the web, podcasting and vidcasting, etc. (Foo \& Ng, 2008; Bawden et al, 2007).

\section{Moving Towards Intellectual Convergence}

The convergence theory is not new in LIS as Shera (1968) considered intellectual convergence of librarianship, documentation, and information science. Pemberton and Nugent (1995) brought together library science, record management, archives management, and information science for a convergence. Since traditional library science education was inadequate, many advocates of the "information paradigm" considered the convergence in library education, and as Raymond (1997) said, they agreed that education for "information management" should take place within existing LIS schools, rather than within computer or MBA/MIS programs. This influence still continues and library education has been amalgamated with many other fields, and hence, LIS curriculum is moving towards an intellectual convergence. As depicted in Figure 1, Durrance (2004) has shown the convergence across various academic programs including library and information science, computer science, management information systems (MIS), medical informatics, and other new information programs that are moving toward an information domain.

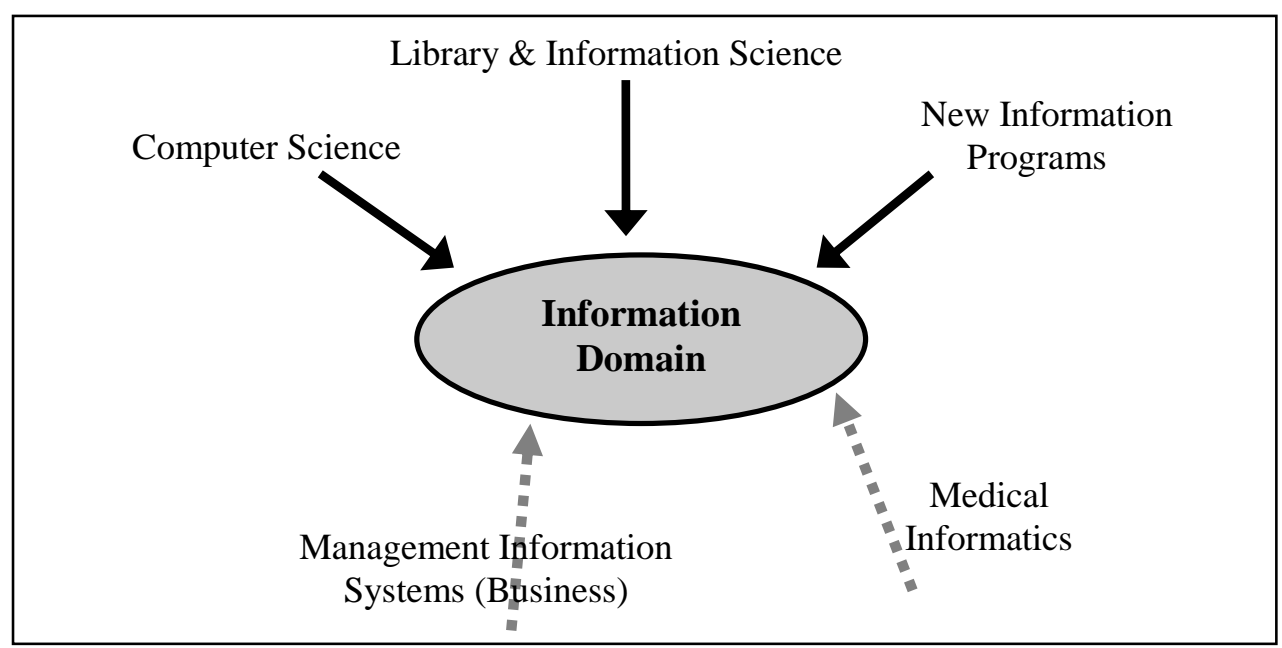

Figure 1: Moving towards intellectual convergence

Source: Durrance (2004) 


\section{Changes in Library Practice and the Profession}

LIS schools usually respond to education relevant to the changes in libraries and professional practice. The trends in education for librarianship indicate that the continual evolution of the information age and the development of digital technologies have altered the traditional concept of libraries, and have made a radical impact on library practices in collecting, organizing, storing, retrieving, and disseminating information globally. These changes have forced library practitioners to rethink and redesign their roles and responsibilities in the information economy.

\section{From Traditional Libraries to Digital Libraries}

The library world witnessed a revolutionary change with the rapid growth of new technologies during the 1980s and the 1990s. Young (1996) argues that librarianship is caught in a sea of dynamic change; preservation, control, and dissemination of recorded knowledge appear to be at risk in a world where uncertainty, contingency, and the transforming nature of electronic media are increasingly dominant. Thus, the overwhelming growth and development of DLs have opened up new horizons in LIS. Fox (1999) explains that the field goes far beyond supporting traditional libraries, addressing core requirements of the information age and the world of information technology, as well as new sub-areas like knowledge management and content management. Lombardi (2000) mentions that the library, we hear, is pretty much over unless it can remake itself into an academic Yahoo, an intellectual Google, or some other competitive hyper-textualized, multi-threaded, linked, digital resource.

\section{From Library Professionals to Information Professionals}

The changes in information environments in library education and practice have transformed the library profession into information profession. Lancaster (1982) argued that librarians in the paperless society "are likely to have responsibilities far beyond those they have at present", and indeed, this might require a name change for the profession. In this changing context of the profession, librarians must abandon their old self-perception as custodians of books, and enter into the new world of information (Apostle \& Raymond, 1986). To work in an information environment, library professionals would require new skills, and Browne (1986) stated a common set of functions for these professionals, including identification of information need, information search design, retrieval of information, evaluation of information, analysis of

10 The Eastern Librarian-peer-reviewed journal in LIS since 1965 
information, synthesis of information, packaging information, repackaging existing information products, dissemination of information, and design and provision of information services.

Observing many technology-oriented tasks of librarians, Lancaster (1991) further comments that "what is happening to the profession? Meetings of librarians now sound like meetings of programmers." The professional competencies in emerging areas like library automation, database creation and retrieval techniques, multi media applications, networking, design and development of library website and digital library, specialization in formats and standards (CCF, UNIMARC, UK-MARC, MARC-21, Dublin Core), and content development have compelled library professionals to be reoriented as information professionals (Rath, 2006). Arguing for the future of the information profession in the evolving information society, Omeka and Eteng (2006) have suggested the reinvention and repositioning of information professionals in order to move with the challenges of digital technology, globalized information access, networked resources, a changing economy, new learning and research systems and the demands of the various user communities for information that adds value to their work.

\section{THE EMERGENCE OF KNOWLEDGE MANAGEMENT AND THE RESPONSES OF LIS}

The concept of knowledge management (KM) was first introduced in a keynote address to a European management conference in 1986 (American Productivity and Quality Center, 1996). At the beginning of the 90s, KM acquired more management attention because of the structural changes in the economy and society towards the information society and knowledge economy (Scholl \& Heisig, 2003). Since the mid-nineties KM has gained much popularity among a number of academic and professional disciplines including LIS (Ponzi \& Koenig, 2002; Chowdhury, 2004; Schlögl, 2005).

\section{LIS's Perceptions of KM}

While a minority of authors like Wilson (2002) rejects the term KM considering it as nonsensical management fad and nothing more than information management, a number of studies have argued for the future of KM. Koenig (2006) mentions that KM seems to be permanent, describing KM as a domain of stable mature growth with no indication of decline of publication volume, a very different profile in comparison to other business fads. KM has a

11 The Eastern Librarian-peer-reviewed journal in LIS since 1965 
future in LIS, and its durability has been confirmed in the studies conducted by Ajiferuke (2003), and Sarrafzadeh, Martin and Hazeri (2006). Davenport and Cronin (2000) describe KM in the LIS context as 'information management' (management of internal and external publications) by another name. Corrall (1998) remarks that librarianship is often used to describe the organization of recorded knowledge, and some people view KM as just an up-market label for information management, hence, she certainly believes that $\mathrm{KM}$ is the job for librarians. Despite a link between information management and knowledge management, many authorities have tried to distinguish KM from librarianship and information management (Southon \& Todd, 2001; Morris, 2001; AlHawamdeh, 2002; Ajiferuke, 2003; Davenport, 2004, and so on). In a study conducted by Roknuzzaman (2009), LIS academics have recognized KM from different viewpoints:

- A very broad and a comprehensive viewpoint

- An inter- and/or a multi-disciplinary point of view

- A process or an information management point of view

- A technology or a systemic point of view

- A strategic or a business point of view

- A managerial or an organizational point of view.

\section{KM Education in LIS}

Although the perceptions and attitudes in the LIS community vary toward KM, most authors view KM through a positive lens, calling for full involvement of LIS in KM programs. Responding to the emerging phenomena of KM, a number of LIS schools have incorporated KM education (Hazeri, 2008; Roknuzzaman, 2009). Education for KM ensures LIS graduates' entrance to the professional workforce equipped to meet the challenges of the new work environment (Milne, 1999). Reardon (1998) observes that information and library science schools have been producing graduates with a wide range of competencies, including information skills, publishing and document design, databases, and information systems and service design. The study conducted by Rehman and Chaudhry (2005) shows that, 7 of the 12 LIS programs in North America, Europe, and Pacific region had graduate level degrees or course work in $\mathrm{KM}$, while 2 had a graduate diploma, and 3 had KM components in their undergraduate courses. Roknuzzaman and Umemoto (2010) have shown that 106 LIS schools of the world provide $140 \mathrm{KM}$ programs/courses in different degree programs, including Certificate, Diploma, Bachelor, Graduate (master's), and Doctoral. KM education is delivered in 91 master's degree

12 The Eastern Librarian-peer-reviewed journal in LIS since 1965 
programs (65\% of the KM programs/courses), followed by 19 (13.6\%) programs/courses for the Bachelor degree, 12 (8.6\%) for Graduate or Post Graduate Certificate, 10 (7.1\%) for Graduate or Post Graduate Diploma, and 8 $(5.7 \%)$ for Doctoral programs.

\section{Practicing KM in Librarianship: From LIS Professionals to Knowledge Professionals}

A number of projects have dealt with the issue of $\mathrm{KM}$ implications in academic, public and corporate libraries (White, 2004; Jantz, 2001; Branin, 2003; Jain, 2007; Selhorst, 2007). KM has brought opportunities for best practice in libraries, and libraries can improve their knowledge-based services for internal and external users through creating an organisational culture of sharing knowledge and expertise within the library (Roknuzzaman \& Umemoto, 2009). There are many technology-supported KM systems in libraries, such as: Common Knowledge Database (CKDB) for acquisition and sharing of informal knowledge of reference librarians (Jantz, 2001); digital institutional repository for intellectual assets (Branin, 2003); wiki for central knowledge base and virtual exchange of knowledge (Selhorst, 2007); etc.

The opportunities emerging from KM can also be seen as challenges for LIS professionals to survive in a competitive and complex environment. Traditionally, information professionals' roles were limited to the identification, acquisition and organization of explicit knowledge or information. Today, that role is being expanded to include other forms of knowledge- tacit and implicit knowledge in the form of skills and competencies. (Al-Hawamdeh et al., 2004). Managing the 'tacit' intuitions and 'know-how 'of organizational members or knowledge workers has become a great challenge for information professionals (Bishop, 2001). Information professionals have to recast their roles as knowledge professionals (Kim, 1999), and since knowledge professionals need to deal with human resource issues as well as organizational issues, a new set of skills and competencies are needed. Ajiferuke (2003) identifies team working, communication, networking and analytical skills as the most important organizational skills required by information professionals to work in KM programs, while understanding of the knowledge process with the business process, ability to use IT, and document management skills are the most important required competencies. Corrall (1998) essentially states that knowledge management requires a mix of technical, organisational and interpersonal skills: the mix and emphasis varies according to responsibilities, but everyone involved needs to be able to understand the business,

13 The Eastern Librarian-peer-reviewed journal in LIS since 1965 
communicate effectively and have at least basic competence in handling information and using IT.

\section{FACTORS WHICH INFLUENCED THE CHANGES IN LIBRARY EDUCATION}

\section{The Role of Information/Knowledge Economy}

The information paradigm, according to many (e.g. Apostle \& Raymond, 1986; Harris, Hannah \& Harris, 1998), is based on the concept of postindustrial societies. Drucker (1969) argued that there is a transition from an economy based on material goods to one based on knowledge. The technological forces of the 1980s and 1990s have accelerated the dynamics and growth of information/knowledge economy. Young (1996) contends that we are hurtling toward a postmodern 'decentered, fragmented, fluid, opaque, and nonlinear cultural' society, which has destabilized the old print order and consequently the nature of librarianship. Roknuzzaman and Umemoto (2009) mention that the value of knowledge has always been a central to library practice, but the new, knowledge-based economy places its significance more on than before from the viewpoint of new theories, frameworks, tools, technologies, and methods in creation, organization and effective diffusion of knowledge. Thus, the proliferation of ICTs and their potential role in library and information work, and other opportunities emerging from the information/knowledge economy have greatly influenced library science to shift its paradigms.

\section{Expansion of the LIS Domain}

Library education has its long history and traditions of introducing emerging areas of information and/or knowledge, considering the changing needs of the information/knowledge society (Roknuzzaman \& Umemoto, 2010). As broad and multidisciplinary fields, both information science and KM can expand the knowledge domain of library science, providing a sound understanding of the underlying concepts, theories, principles, techniques, and technologies of information management and KM.

\section{Emerging Employment Market}

The initial appeal of the information paradigm, as described by Apostle (1997), was tied to the prospect that new job markets and opportunities would emerge as the information economy expanded. Within this context, several studies identified the market opportunities for information professionals (Moore, 1987;

14 The Eastern Librarian-peer-reviewed journal in LIS since 1965 
Apostle \& Raymond, 1991). Similarly a number of authors describe that KM offers new career options and new job opportunities for graduates (Morris, 2001; Rehman \& Chaudhry, 2005; Sarrafzadeh, Martin \& Hazeri, 2006). Responding to the needs of current and future employers for information and knowledge professionals in the fast moving and exciting area of KM, LIS schools have adopted KM education.

\section{Survival in the Competitive Academic Environment}

Besides the intellectual issues, there was a strong political reason for the survival of library schools in the context of the decline of traditional job markets for library school graduates. The employment opportunities which emerged from the information industry were not reserved for library science graduates. Cronin, Stiffler and Day (1993) pointed out that it was not a captive or guaranteed market, as competition from other suppliers and skepticism about the ability of LIS schools to adapt, pedagogically and culturally, to the dynamics of a changing marketplace feature strongly. Thus, LIS schools have the political motivation of attracting more students into LIS education with the inclusion of both information science and KM programs in one hand, and the LIS graduates with information/KM education, on the other hand, can find a position in information/knowledge management environment, competing with graduates from other disciplines.

\section{CONCLUSION: PREDICTION ABOUT KNOWLEDGE SCIENCE}

The library education encountered a revolutionary change with the emergence of the field of information science after the World War II. During the last few decades, LIS has transformed itself into an almost new field of practice (Rehman, 2006), and this transformation is demonstrated by an evolutionary shift within the discipline from Library Studies to Information Science to Knowledge Management (Hillenbrand, 2005). Despite the mixed feelings of the library science community towards information science, both fields have been amalgamated following a partial adoption process. The integration of information science with library science is dominated by 'information paradigm', and this paradigm shift has forced library schools to rename as library and information science with revision of library science curricula. The information science revolution has also altered the traditional face of librarianship and has changed the library professionals to information professionals.

15 The Eastern Librarian-peer-reviewed journal in LIS since 1965 
LIS is now being encountered with another emerging filed called knowledge management. A number of LIS schools have incorporated KM education, and the professionals are practicing $\mathrm{KM}$ in library environment. It is predicted that the information paradigm is moving towards knowledge paradigm. The term 'library' still has a great appeal in the knowledge society, and many new terms are coming up including the word "library", e.g. 'digital library', 'virtual library', 'electronic library', 'social library', 'web library', 'library 2.0', and more. The information, technology, human and business perspectives of KM are suited for the library environment. We think that LIS has regained its turf through the incorporation of KM. We just need to redefine 'library' from broader perspectives that reflect the changing needs of the knowledge society. A number of LIS academics of the world, as Roknuzzaman (2009) found, have suggested that the name "Library and Information Science" should be changed to "Information and Knowledge Management", "Knowledge and Information Management", "Information and Knowledge Studies", etc. This group of academics considered themselves as "information and/or knowledge professionals", and they suggested the name of the profession as "information and/or knowledge profession." On the other hand, a number of respondents (around 30\%) were content with the existing names of the discipline "Library and Information Science", "Library and Information Studies", "Information Science", "Information Studies", "I-school, etc., and they considered themselves as "information professionals."

The fact is that many "information science schools" and "I-schools" do not fall under the scope of LIS. Some information science schools are strongly business and/or information technology oriented, and they do not offer any library science course. Some schools do not even allow the enrollment of any LIS student in their KM programs. Therefore, we need to know "who we are and where we are from." Alimohammadi and Sajjadi (2007) asserted that, in 1977, in his classic book entitled Understanding Knowledge Science, Ebrami provided a well-structured and detailed discussion about the history and function of the library as the repository of human knowledge and, at the same time, as a communication tool. Ebrami also argued that "Library and Information Science" should be renamed "Knowledge Science", because librarians are in fact manipulating knowledge - that is, the product of information processing in the form of information carriers/containers - not just information (Ebrami, 1977). Zins (2005) also suggested the name "Knowledge Science" instead of "Information Science." The University of Tsukuba in Japan also renamed one of their undergraduate programs the "College of Knowledge

16 The Eastern Librarian-peer-reviewed journal in LIS since 1965 
and Library Sciences." Yanagi (2009, pp.158-159) argues that LIS, along with $\mathrm{KM}$, could contribute to the establishment of knowledge science. He suspects, however, that it may be difficult for LIS to evolve into knowledge science.

In fact, LIS deals with data, information, and knowledge, but the philosophical and epistemological level of knowledge is higher than that of data and information. 'Knowledge' incorporates 'information' that has been interpreted, analysed and assimilated. Considering the historical link of the library with knowledge and culture, and the emerging field of KM, as well as the above facts, we suggest that LIS academics and practitioners should rename the LIS discipline as "Library and Knowledge Science", and the profession as "Library and Knowledge Profession."

\section{REFERENCES}

Ajiferuke, I. (2003). Role of information professionals in knowledge management programs: Empirical evidence from Canada. Informing Science Journal, 6, 24757.

Al-Hawamdeh, S. (2002). Knowledge management: Re-thinking information management and facing the challenge of managing tacit knowledge. Information Research, 8(1).

Al-Hawamdeh, S., Froehlich, T.J., Srikantaiah, T. K., Chaudhry, A.S., Chang, Y. and Morales- Arroyo, M.A. (2004). Challenges in knowledge management education. Proceedings of the American Society for Information Science and Technology, 41(1), 605-606.

Alimohammadi, D. and Sajjadi, M. (2007). What our schools are named? An investigation among information leaders. VINE: The Journal of Information and Knowledge Management Systems, 37 (4), 532-546.

American Productivity and Quality Center (1996). Knowledge management consortium benchmarking study. Houston TX: American Productivity and Quality Center.

Apostle, R. and Raymond, B. (1986). Librarianship and the information paradigm. Canadian Library Journal, 43(6), 377-384.

Apostle, R. and Raymond, B. (1991). Library and information work in Canada: Analysis of an emerging labor market. Canadian Journal of Information Science, 16(2), 40-51.

Artandi, S. (1969). The relevance of information science to library-school curricula. American Documentation, 20(4), 337-338.

17 The Eastern Librarian-peer-reviewed journal in LIS since 1965 
Bawden, D., Robinson, L., Anderson, T., Bates, J., Rutkauskiene, U. and Vilar, P. (2007). Towards curriculum 2.0: Library/information education for a web 2.0 world. Library and Information Research, 31(99), 14-25.

Belzer, J., Williams, J., Kronebusch, J., and Gupta, A. B. (1975). Curricula in information science: Four year progress report. Journal of the American Society for Information Science, 26(1), 17-32.

Bishop, K. (2001). Leveraging our knowledge: The skills and attributes information professionals bring to new roles in information and knowledge management. ALIA Conferences: $9^{\text {th }}$ Specials, Health and Law Libraries Conference, Melbourne, Australia, August 26-29.

Borko, H. (1968). Information science: What is it? Journal of the American Society for Information Science, 19, 3-5.

Borko, H. (1984). Trends in library and information science education. Journal of the American Society for Information Science, 35(3), 185-193.

Branin, J.J. (2003). Knowledge management in academic libraries: Building the knowledge bank at the Ohio State University. Retrieved from <http://kb.osu.edu/dspace/bitstream/1811/187/1/KBJAL.pdf $>$.

Browne, M. (1986). Disciplinary study in information science: A foundation for the education of information professionals. Education for Information, 4, 305-318.

Burgess, S.F. and Edwards, S.E. (1990). The transformation of library education in Australia. Education for Information, 8(2), 117-138.

Carnovsky, L. (1964). Role of public library: Implications for library education. Library Quarterly, 34, 315-325.

Chowdhury, G. (2004). Knowledge organization or information organization: A key component of knowledge management activities. Paper presented at The International Conference on Digital Libraries, New Delhi, India, Feb. 24-27.

Colson, J.H. (1980). Professional ideals and social reality: Some questions about the education of librarians. Journal of Education for Librarianship, 21(2), 91-108.

Corrall, S. (1998). Knowledge management: Are we in the knowledge management business? ARIADNE-The web version, 18(December) [Online].

Cronin, B., Stiffler, M. and Day, D. (1993). The emergent market for information professionals: Educational opportunities and implications. Library Trend,42(2), 257-276.

Davenport, E. and Cronin, B. (2000). Knowledge management: Semantic drift or conceptual shift? Journal of Education for Library and Information Science, 41(4), 294-306.

Davis, C.H. and Shaw, D. (1981). A brief look at introductory information science in library schools, 1980. Journal of Education for Librarianship, 21(4), 341-343.

Drucker, P. (1969). The Age of discontinuity. London: Heinemann.

18 The Eastern Librarian-peer-reviewed journal in LIS since 1965 
Durrance, J.C. (2004). Competition or convergence? Library and information science education at a crossroad. Advances in Librarianship, 28, 171-198.

Ebrami, H. (1977). Understanding knowledge science. Tehran: Iranian Library Association.

Foo, S. and Ng, J. (2008). Library 2.0, libraries and library School. In Proceedings of the Library Association of Singapore Conference 2008, Singapore, May 8-9.

Fosdick, H. (1978). Library education in information science: Present trends. Special Libraries, 69(3), 100-108.

Fosdick, H. (1984). Trends in information science education. Special Libraries, 75(4), 292-302.

Fox, E.A. (1999). From theory to practice in digital libraries: $5 S$ and educational applications (NDLTD, CSTC). Paper prepared for NSF-CONACyT-ISTEC Workshop on Digital Libraries, Albuquerque, New Mexico, USA, July 7-9.

Galvin, T.J. (1995). Convergence or divergence in education for the information professions: An opinion paper. Bulletin of the American Society for Information Science, 21(6), 7-14.

Garfield, E. (1980). Information science education: An ivory Tower of Babel?, Current Contents, 22(2), 5-13.

Gleaves, E.S. (1982). Library education: Issues for the eighties. Journal of Education for Librarianship, 22(4), 260-274.

Harris, M.H., Hanna, S.A. and Harris, P. (1998). Info the future: The foundation of library and information services in the post-industrial era (2nd ed.). London: Ablex Publishing.

Hawkins, B. (2000). Libraries, knowledge management, and higher education in an electronic environment. In ALIA 2000 Proceedings. Retrieved from http://www.alia.org.au/conferences/alia2000/proceedings/brian.hawkins.html.

Hayes, R.M. (1969). Information science in librarianship. Libri, 19(3), 216-236.

Hayes, R.M. (1994). Information science and librarianship. In W.A. Wiegand, \& D. G. Davis Jr. (Eds.), Encyclopedia of Library History (pp.275-280). New York: Garland Publishing.

Hazeri, A. (2008). The implications of knowledge management for library and information science education: A mixed method investigation, Unpublished Ph.D. Dissertation, School of Business Information Technology, RMIT University, Australia.

Hillenbrand, C. (2005). Librarianship in the 21st century - crisis or transformation? The Australian Library Journal, 54(2).

Jain, P. (2007). An empirical study of knowledge management in academic libraries in East and Southern Africa. Library Review, 56(5), 377-392.

Jantz, R. (2001). Knowledge management in academic libraries: Special tools and processes to support information professionals. Reference Service Review, 29(1), 33-39.

19 The Eastern Librarian-peer-reviewed journal in LIS since 1965 
KALIPER Advisory Committee (2000). Educating library and information science professionals for a new century: The KALIPER report. Executive summary. Reston, VA: Association for Library and Information Science Education (ALIES), July 2000.

Kim, S. (1999). The roles of knowledge professionals for knowledge management. Paper presented at the $65^{\text {th }}$ IFLA Council and General Conference, Bangkok, Thailand, August 20-28.

Koenig, M.E.D. (2006). Leadership roles for information professionals. In Khoo, C., Singh, D., \& Chaudhry, A.S. (Eds.), Proceedings of the A-LIEP 2006: AsiaPacific Conference on Library \& Information Education \& Practice (pp.11-17). Singapore, April 3-6, 2006.

Lancaster, F.W. (1982). The future of libraries in the age of telecommunications. In R. E. Hoover (Ed.), Changing information concepts and technologies (pp.137-156). White Plains, NY: Knowledge Industries.

Lancaster, F.W. (1991). Has technology failed us? In A. H. Helal, \& J. W. Weiss (Eds.), Information technology and library management (pp.3-13). 13th International Essen Symposium. Essen, Germany: Universitatsbibliothek.

Langridge, D.W. (1978). Teaching and organization of knowledge. In G. Peter (Ed.), Education for librarianship: Decisions in organizing a system of professional education (pp.104-114). Hamden, Con.: The Shoe String Press.

Logan, E. and Hsieh-Yee, I. (2001). Library and information science education in the nineties. Annual Review of Information Science and Technology, 35, 425-477.

Lombardi, J.V. (2000). Academic libraries in a digital age. D-Lib Magazine, 6(10).

Retrieved June 9, 2007, from www.dlib.org/dlib/october00/lombardi/10lombardi.html

Milne, P. (1999). Knowledge Management and LIS Education. Education for Library and Information Services: Australia (ELIS: A), 16(3), 31-38.

Moore, N. (1987). The emerging markets for librarians and information workers (Library and information research report 56). London, England: British Library, Research and Development Department.

Morris, A. (2001). Knowledge management: opportunities for LIS graduates. Paper presented at the 67th IFLA Council and General Conference, Boston, USA, August 16-25.

Myburgh, S. (2003). Education directions for new information professionals. Australian Library Journal, 52(3), 213-227.

Nitecki, J.Z. (1993). Metalibrarianship: A model for intellectual foundations of library information science, 1 . Retrieved from http://www.twu.edu/library/nitecki/ metalibrarianship/index.html

Omekwa, C.O. and Eteng, U. (2006). Roadmap to change: Emerging roles for information professionals. Library review, 55(4), 267-277.

20 The Eastern Librarian-peer-reviewed journal in LIS since 1965 
Pemberton, M. and Nugent, C.R. (1995). Information studies: Emergent filed, convergent curriculum. Journal of Library and Information Science, 36(2), 126138.

Pettigrew, K.E. (2001). KALIPER: Introduction and overview of results. Journal of Education for Library and Information Science 43(3), 170-181.

Ponzi, L.J. and Koenig, M. (2002). Knowledge management: Another management fad? Information Research, 8(1).

Rath, P. (2006). Preparing library and information professionals for the 21 st century: Issue and challenges for library and information science educators in India. In C. Khoo, D. Singh, \& A.S. Chaudhry (Eds.), Proceedings of the Asia-Pacific Conference on Library \& Information Education \& Practice 2006 (ALIEP 2006), Singapore (pp. 35-40). April 3-6, 2006. Singapore: Nanyang Technological University.

Raymond, B. (1997). Paradigm in conflict. In R. Apostle and B. Raymond (Eds.), Librarianship and the information paradigm (pp.1-36). London: The Scarecrow Press.

Reardon, D.F. (1998). Knowledge management: The discipline for information and library science professionals. Paper presented at the 64th IFLA Council and General Conference, Amsterdam, August 16-21.

Rehman, S.U. (2006). New age competencies for information professionals. In C. Khoo, D. Singh and A.S. Chaudhry (Eds.), Proceedings of the Asia-Pacific Conference on Library \& Information Education \& Practice 2006 (A-LIEP 2006), Singapore, April 3-6, 2006 (pp.27-34). Singapore: Nanyang Technological University.

Rehman, S.U. and Chaudhry, A.S. (2005). KM education in LIS programs. Paper presented at the 71th IFLA General Conference and Council, Oslo, Norway, August 14-18.

Richardson, J.V. (1982). The spirit of inquiry: The Graduate Library School at Chicago, 1921-1951. Chicago: American Library Association.

Roknuzzaman, M. (2009). When existing and emerging disciplines meet: Library and information science vs knowledge management. Unpublished $\mathrm{PhD}$ Dissertation, School of Knowledge Science, Japan Advanced Institute of Science and Technology (JAIST), Japan.

Roknuzzaman, M. and Umemoto, K. (2009). How library practitioners view knowledge management in libraries: A qualitative study. Library Management, 30(8/9), 643-656.

Roknuzzaman, M. and Umemoto, K. (2010). KM education at LIS schools: An analysis of KM master's programs. Journal of Education for Library and Information Science, 51(4), 267-280.

Saracevic, T. (1979). An essay on the past and future of information science education-II: Unresolved problems of "externalities" of education. Information Processing and Management, 15, 291-301.

21 The Eastern Librarian-peer-reviewed journal in LIS since 1965 
Saracevic, T. (1982). Time for divorce: Setting up degree programs in information science. Bulletin of the American Society for Information Science, 8(June), 32.

Saracevic, T. (1992). Information science: Origin, evolution and relations. In P. Vikkari, \& B. Cronin (Eds.), Conceptions of library and information science: Historical, empirical and theoretical perspectives (pp.5-27). Los Angeles, CA: Taylor Graham.

Sarrafzadeh, M. (2005). The implications of knowledge management for the library and information professions. actKM Online Journal of Knowledge Management, 2(1), 92-102.

Sarrafzadeh, M., Martin, B. and Hazeri, A. (2006). LIS professionals and knowledge management: Some recent perspectives. Library Management, 27(9), 621-635.

Schlögl, C. (2005). Information and Knowledge Management: Dimensions and Approaches. Information Research, 10(4).

Scholl, W. and Heisig, P. (2003). Delphi study of the future of knowledge management: Overview of the results. In K. Mertins, P. Heisig, \& J. Vorbeck (Eds.), Knowledge management: Concepts and best practices $\left(2^{\text {nd }}\right.$ ed.) (pp.179187). Berlin: Springer.

Schrader, A.M. (1995). One field or two? A definitional analysis of the relationship between library science and information science. Retrieved from http://eric.ed.gov/ERICDocs/data/ericdocs2/content_storage_01/0000000b/80/23/ c1/56.pdf

Selhorst, K. (2007). A framework for knowledge management in a public library: Based on a case study on knowledge management in a Dutch Public Library. Paper presented at the $8^{\text {th }}$ European Conference on Knowledge Management, Barcelona, Spain, September 6-7.

Shera, J.H. (1968). Of librarianship, documentation, and information science. UNESCO Bulletin for Libraries, 22(March/April), 58-65.

Southon, G. and Todd, R. (2001). Library and information professionals and knowledge management: Conceptions, challenges and conflicts. The Australian Library Journal, 50(3), 259-282.

Steig, M.F. (1992). Change and challenge in library and information science education. Chicago: American Library Association.

Svenonius, E. and Witthus, R. (1981). Information science as a profession. Annual Review of Information Science and Technology, 16, 291-316.

Swanson, D.R. (1965). Introduction. In Intellectual Foundation of Library Education, Proceedings of the twenty-ninth Annual Conference of the Graduate Library School (p.2). Chicago: University of Chicago Press.

Tague, J. (1979). Information science in graduate library programs. Canadian Library Journal, 36(3), 89-99.

Taylor, R.S. (1966). Professional aspects of information science and technology. Annual Review of Information Science and Technology, 1, 15-40. 
Van House, N.A. and Sutton, S.A. (1996). The panda syndrome: An ecology of LIS education. Journal of Education for Library and Information Science, 37(2), 131147.

Wen, S. (2005). Implementing knowledge management in academic libraries: A pragmatic approach. Paper presented at The 3rd China-US Library Conference, Shanghai, China, March 22-25.

White, T. (2004). Knowledge management in an academic library: Based on the case study KM within OULS. Paper presented at the 70th IFLA General Conference and Council, Buenos Aires, August 22-27.

Wilson, A.M. and Hermanson, R. (1998). Educating and training library practitioners: A comparative history with trends and recommendations- includes appendix on history of library education. Library Trends, 46(3), 467-504.

Wilson, T.D. (2002). The nonsense of 'knowledge management'. Information Research, 8(1).

Yanagi, Y. (2009). Knowledge management and library. Tokyo: Keisou Shobou (in Japanese).

Young, P.R. (1996). Librarianship: A changing profession, Daedalus, 125(4), 103-25.

Zins, C. (2005). Redefining information science: From "information science" to "knowledge science". Journal of Documentation, 62(4), 447-461. 